\title{
PENGARUH GAME ONLINE ANDROID TERHADAP PRESTASI BELAJAR SISWA KELAS IV MI ISLAMIYAH KEBOMLATI KECAMATAN PLUMPANG KABUPATEN TUBAN TAHUN PELAJARAN 2017-2018
}

\author{
Agus Fathoni Prasetyo, email : agusfathoni@stitmatuban.ac.id \\ Dinna Shofia
}

\begin{abstract}
Progress in the field of communication technology in the current era of globalization is producing sophisticated media so as to facilitate the needs needed quickly. In the past few years the android online game play on smartphones has been very interested in most circles, especially students. The positive impact of online games is that the more difficult a game is, the more high levels of concentration are needed to improve hand and eye coordination, while the negative impact of this android online game is that students often forget about other activities and forget their assignments as students. This research was conducted with a quantitative approach. The form of this research is correlational. The subjects in this study were fourth grade students of MI Islamiyah Kebomlati, Plumpang Subdistrict, Tuban District, 2017/2018 Academic Year, with 18 students consisting of 8 male students and 10 female students. The use of android online games for grade IV MI Islamiyah Kebomlati students in Plumpang sub-district of Tuban in the 2017/2018 academic year is sufficient or moderate. Because the average value of 25.5. The effect of android online games on the learning achievement of fourth grade MI Islamiyah Kebomlati Districts Plumpang District of Tuban in the academic year 2017/2018 based on the results of research on interpretation using the t-table value $r 2$ determinaation coefficient, it turns out that the t-count () is smaller than t-table, at the significance level of 5\% (2,120). Thus there is an insignificant coefficient of determination between android online games and the learning achievement of fourth grade students of MI Islamiyah Kebomlati, Plumpang Subdistrict, Tuban Regency in the academic year 2017/2018. This shows that the android online game has no effect on student achievement IV MI Islamiyah Kebomlati Plumpang District of Tuban in the 2017/2018 academic year.
\end{abstract}

Keywords: Android Online Game, Student Learning Achievement 


\section{A. Pendahuluan}

Pendidikan sebenarnya adalah proses yang tanpa akhir (education is the process without end). Dan pendidikan merupakan proses pembentukan kemampuan dasar yang foundamental, baik menyangkut daya fikir (daya intelektual) maupun emosional (perasaan) yang diarahkan kepada tabiat manusia kepada sesamanya. Karena begitu pentingnya pendidikan bagi seorang anak untuk menunjang masa depan.

Kemajuan dibidang teknologi komunikasi dalam masa globalisasi saat ini menghasilkan media yang canggih sehingga mempermudah keperluan yang dibutuhkan dengan cepat. Menurut Friedman ${ }^{1}$, Globalisasi adalah sebuah sistem netral. Globalisasi bisa berpengaruh positif ataupun negatif. Bisa memperkuat atau melemahkan sandi-sandi kehidupan, menyeragamkan atau memplorisasikan, juga mendemokratisasikan atau justru sebaliknya. Itu semua tergantung bagaimana kita meresponnya.

Dalam waktu beberapa tahun terakhir ini permainan game online android di smartphone sangat di minati sebagian besar kalangan, terutama para siswa. Game satu ini mempunyai daya tarik tersendiri, selain mode permainan yang selalu berkesinambungan, game online android ini juga dapat dimainkan dengan pengguna melalui jaringan Internet

Dampak positif adanya game online adalah semakin sulit sebuah game maka semakin diperlukan tingkat konsentrasi yang tinggi untuk meningkatkan koordinasi tangan dan mata. Sangat tidak beralasan bahwa game online merupakan jenis permainan yang menurunkan tingkat minat baca anak. Dalam hal ini justru game online dapat meningkatkan minat baca pemainnya. Meningkatkan kemampuan berbahasa Inggris, karena kebanyakan game online menggunakan bahasa Inggris dalam pengoperasiannya ini yang mengakibatkan pemainnya harus mengetahui kosa kata bahasa Inggris.

Dampak negatif dari game online android ini adalah siswa sering lupa dengan aktifitas lain dan melupakan tugasnya sebagai siswa. Permainan ini juga membawa dampak buruk bagi kesehatan siswa yang terlalu sering memainkannya, karena pancaran cahaya yang muncul pada layar smartphone dapat merusak kornea mata. Selain itu game online android juga membutuhkan paket data yang digunakan untuk menghubungkan game ke internet, dan hal itu akan menambah biaya lebih untuk memainkannya.

\footnotetext{
${ }^{1}$ Thomas L Friedman. 2000 Pengertian Globalisasi Jakarta: Balai Pustaka. Hal: 46
} 
Penyediaan sarana belajar yang baik merupakan salah satu faktor yang dapat memberikan pengaruh terhadap keberhasilan anak dalam meraih pendidikan. Anak sangat membutuhkan fasilitas yang dapat menunjang kegiatan pembelajaran. Dibandingkan dengan negara lain, kita banyak tertinggal jauh dalam hal penyediaan sarana belajar bagi anak. Jika negara lain telah mengenalkan anak pada dunia teknologi sejak belasan tahun yang lalu, namun kita baru saja memulainya dan itu pun belum menyebar secara menyeluruh hingga ke daerah pelosok.

Sementara itu, orang tua yang memiliki tingkat pendidikan yang lebih tinggi pasti memiliki sumber daya yang cenderung lebih besar, baik pendapatan, waktu, tenaga dan jaringan kontak, yang memungkinkan mereka untuk terlibat lebih jauh dalam pendidikan anak. Orang tua dengan tingkat pendidikan yang lebih tinggi juga akan lebih percaya diri pada kemampuan mereka dalam membantu anak-anak belajar. Dengan tingkat pendidikan tersebut maka akan berpengaruh terhadap hasil belajar anak. Peran orang tua juga sangat penting disini terutama untuk mengawasi dan membimbing anaknya agar tidak terjadi hal-hal yang tidak diinginkan yang mengarah pada hal-hal yang negatif.

Terdapat beberapa faktor yang mempengaruhi hasil belajar anak, salah satunya adalah kebiasaan dan tingkah laku siswa. Game online android yang dimainkan siswa secara berlebihan akan berpengaruh terhadap hasil belajar siswa. Kondisi tersebut juga berdampak pada siswa kelas IV MI Islamiyah Kebomlati Kecamatan Plumpang Kabupaten Tuban. Berdasarkan pengamatan peneliti masih terdapat beberapa siswa kelas IV MI Islamiyah Kebomlati Kecamatan Plumpang Kabupaten Tuban yang hasil belajarnya masih di bawah standar KKM (kriteria ketuntasan minimum), sedangkan hampir semua siswa mempunya handpone android dan bermain game online. Dilandasi hal tersebut maka peneliti tertarik untuk melakukan penelitian secara lebih dalam bagaimana pengaruh game online android terhadap prestasi belajar siswa.

\section{B. Kajian Teori}

\section{Pengertian Game Online Android}

Game online android adalah gabungan dari tiga kata yang berasal dari bahasa inggris. Game artinya adalah permainan, Online artinya adalah Daring (Dalam Jaringan) dan Android adalah sistem operasi yang diselamatkan dalam smartphone ataupun komputer atau sistem 
android inilah yang nantinya menyediakan beragam kebutuhan dari pengguna smartphone ${ }^{2}$. Game adalah suatu permainan yang sangat dinikmati di semua kalangan game ini membawa daya tarik tersendiri bagi penggemar game. Game tidak pernah mengenal umur dan status kemasyarakatan, semua kalangan boleh menikmati game, tua-muda, kaya-miskin, maupun priawanita semua boleh menikmati game.

Game online yang sederhana dan yang terumit pun tersedia dan gampang untuk didapatkan. Kecuali bila harus membeli user dan tentunya game online dapat dikategorikan dalam dunia maya. Dapat ditemui disekitar kita warung internet khusus game online yang kadang disebut warnet game. Dan terkadang dipasang poster-poster game yang sedang naik daun pada zaman sekarang.

Sedangkan game online android adalah permainan yang terhubung dalam jaringan internet yang dimainkan dengan menggunakan smartphone android. Game ini membawa daya tarik tersendiri bagi penggemar game, karena jenis permainannya dimainkan antara pengguna game online lainnya. Game online android juga mempunyai jenis misi yang berkelanjutan dan menarik sehingga tidak membuat rasa bosan penikmat game. Selain itu, game ini menyediakan tampilan visual tinggi yang menghasilkan tampilan gambar yang bagus dan lebik kelihatan hidup atau nyata.

\section{Dampak Game Online Android}

Mendengar kata game kita pasti mengasumsikan dengan bermain, kata yang tidak asing sering digunakaan untuk sarana bermain dengan menghilangkan rasa bosan. Tidak asing bagi kaum anak-anak, remaja dan bahkan orang dewasa sekalipun, tentunya game memiliki dampak positif dan negatif bagi yang memainkannya, menurut Hemiah dampak positif dan negatif sebagai berikut ${ }^{3}$ :

a. Dampak positif game online Setiap game memiliki tingkat kesulitan Level yang berbeda. Umumnya permainan ini dilengkapi pernak-pernik senjata, amunisi, karakter dan peta permainan yang berbeda. Untuk menyelesaikan level atau mengalahkan musuh secara efisien diperlukan strategi. Permainan game online akan melatih pemainnya untuk

\footnotetext{
2 Rahim, Fitra. 2016. Pengertian Game Online, (Online), pada https://simpledukasi.blogspot.co.id. Diakses 30 Desember 2017.

3 Hemiah, Iyanne. 2014. Dampak game Online Android, (Online), pada https://simpledukasi.blogspot.co. Diakses 30 Desember 2017.
} 
dapat memenangkan permainan dengan cepat, efisien dan menghasilkan lebih banyak poin. Kemampuan konsentrasi pemain game online akan meningkat karena mereka harus menyelesaikan beberapa tugas, mencari celah yang mungkin bisa dilewati dan memonitori jalannya permainan. Selain itu, game juga meningkatkan kemampuan membaca, Sangat tidak beralasan bahwa game online merupakan jenis permainan yang menurunkan tingkat minat baca anak. Dalam hal ini justru game online dapat meningkatkan minat baca pemainnya serta meningkatkan kemampuan berbahasa Inggris.

b. Dampak negatif dari game online android ini adalah siswa sering lupa dengan aktifitas lain dan melupakan tugasnya sebagai siswa. Permainan ini juga membawa dampak buruk bagi kesehatan siswa yang terlalu sering memainkannya, karena cahaya yang muncul pada layar smartphone dapat merusak kornea mata. Selain itu game online android juga membutuhkan paket data yang digunakan untuk menghubungkan game ke internet, dan hal itu akan menambah biaya lebih untuk memainkannya.

\section{Faktor-Faktor yang Mempengaruhi Prestasi Belajar}

Prestasi belajar juga menentukan sejauh mana daya serap yang dicapai siswa dalam belajar, daya serap yang tinggi akan digambarkan prestasi belajar yang tinggi, daya serap yang rendah akan digambarkan prestasi yang rendah pula. Maka dalam hal tersebut dimana daya kemampuan yang berbeda-beda dapat disebabkan adanya faktor-faktor yang mempengaruhinya. Tingkat intelegensi siswa memang salah satu faktor yang mempengaruhi prestasi belajar, namun hal tersebut bukanlah faktor utama, ada faktor-faktor lain yang mendukung pretasi belajar yang diperoleh siswa.

Seperti yang dinyatakan oleh Slameto bahwa prestasi belajar siswa tidak semata-mata ditentukan oleh tingkat kemampuan intelektualnya, tetapi ada faktor-faktor lain yang mempengaruhinya seperti motovasi, sikap, kesehatan fisik dan mental, kepribadian, ketekunan dan lain-lain. Secara umum faktor yang mempengaruhi prestasi belajar terbagi menjadi dua, yaitu faktor intern dan faktor ekstern ${ }^{4}$.

\footnotetext{
${ }^{4}$ Feances F. Merril. 1995 Pengertian Keluarga Jakarta Erlangga. Hal: 130
} 
selanjutnya adalah faktor ekstern yang mempengaruhi prestasi belajar, faktor ekstern yang mempengaruhi prestasi belajar meliputi ${ }^{5}$

a. Keluarga

Keluarga adalah ayah, ibu dan anak-anak serta family yang menjadi penguni rumah. Faktor orang tua itu sangat besar pengaruhnya terhadap keberhasilan anak dalam belajar. Tinggi rendahnya pendidikan orang tua, besar kecilnya penghasilan, cukup tidaknya perhatian dan bimbingan orang tua, rukun atau tidaknya orang tua, akrab atau tidaknya hubungan orang tua dengan anak-anaknya, tengan atau tidaknya situasi dalam rumah, semuanya itu turut mempengaruhi pencapaian hasil belajar anak.

b. Sekolah

Keadaan sekolah tempat belajar turut mempengaruhi tingkat keberhasilan belajar. Kualitas guru, metode mengajarnya, media pembelajarannya, kesesuaian kurikulum dengan kemampuan anak, keadaan fasilitas/perlengkapan di sekolah, keadaan ruangan, jumlah murid per kelas, pelaksanaan tata tertib sekolah dan lain sebagainya. Semua itu turut mempengaruhi keberhasilan belajar anak.

c. Masyarakat

Keadaan masyarakat juga mempengaruhi prestasi belajar. Bila di sekitar tempat tinggal keadaan masyarakatnya terdiri dari orang-orang yang berpendidikan, terutama anak-anaknya rata-rata bersekolah tinggi dan moralnya baik, hal ini akan mendorong anak lebih giat belajar. Namun sebaliknya, apabila tinggal di lingkungan banyak anak-anak yang nakal, tidak sekolah dan pengangguran, hal ini akan mempengaruhi semangat belajar atau dapat dikatakan tidak menunjang sehingga motivasi belajar juga berkurang.

\section{d. Lingkungan Sekitar}

Kedaan lingkungan tempat tinggal juga sangat penting dalam mempengaruhi prestasi belajar. Keadaan lingkungan, bangunan rumah, suasana sekitar, keadaan lalu lintas, iklim dan lain sebagainya. Misalnya bila bangunan rumah penduduk sangat rapat, hal itu akan mengganggu proses belajar. Keadaan lalu lintas yang membisingkan, suara hiruk-pikuk orang sekitar, suara pabrik, polusi udara, iklim yang terlalu panas, semuanya ini akan

\footnotetext{
${ }^{5}$ Sudjana, Nana. 2009. Faktor-faktor Yang Mempengaruhi Prestasi Belajar. Jambi: Wakapolda. Hal: 45-48
} 
mempengaruhi kegairahan belajar. Sebaliknya tempat yang sepi dengan iklim sejuk, itu juga akan menunjang proses belajar.

\section{Metode Penelitian}

Penelitian ini dilakukan dengan pendekatan kuantitatif, peneliti mengangkakan data temuanya pada variabel bebas game online android dan variabel terikat prestasi belajar siswa serta memproses dan menghitung angka-angka tersebut untuk mencari ada dan tidaknya pengaruh game online android terhadap prestasi belajar, serta seberapa signifikan pengaruh tersebut, jika ada.

Bentuk penelitian ini adalah korelasional. Peneliti menentukan subyek penelitian berdasarkan permasalahan yang akan diteliti, tentang pengaruh game online android terhadap prestasi belajar dan subyek dalam penelitian ini adalah siswa kelas IV MI Islamiyah Kebomlati Kecamatan Plumpang Kabupaten Tuban Tahun Pelajaran 2017/2018, dengan jumlah siswa 18 orang, terdiri dari 8 siswa laki-laki dan 10 siswa perempuan. Variasi jenis instrumen penelitian adalah: angket, ceklis (chek-list) atau daftar centang, pedoman wawancara, pedoman pengamatan 6. Untuk mencari varians variabel dapat digunakan teknik statistik dengan menghitung besarnya Koefisien determinasi. Koefisien determinasi dihitung dengan megkuadratkan koefisien korelasi yang telah ditemukan, dan selanjutnya dikalikan dengan 100\%. Koefisien determinan (penentu) dinyatakan dalam persen.

Langkah-langkah yang dilakukan untuk menganalisis data dalam penelitian ini adalah sebagai berikut:

1. Analisis pendahuluan

2. Analisis Uji Hipotesis

3 Analisis Tindak Lanjut

\section{Hasil dan Pembahasan}

1. Penggunaan Game Online Android Siswa Kelas IV MI Islamiyah Kebomlati Tahun Pelajaran 2017/2018

\footnotetext{
${ }^{6}$ Arikunto, Suharsimi. 2010. Prosedur Pengumpulan Data. Jakarta: PT Rineka Cipta. Hal: 203
} 
Data yang akan peneliti sajikan adalah data tentang penggunaan game online android siswa kelas IV MI Islamiyah Kebomlati tahun pelajaran 2017/2018. Data tersebut diperoleh dengan metode angket yang akan dikuatkan dengan hasil observasi dan wawancara, kemudian dari angket tersebut peneliti memperoleh data yang berupa jawaban angket yang masih berwujud data kualitatif. Kemudian dari data tersebut peneliti mengubahnya menjadi data kuantitatif yaitu dengan memberi nilai berdasarkan skor yang telah ditentukan.

Selanjutnya peneliti akan menyajikan data hasil angket tentang penggunaan game online android siswa kelas IV MI Islamiyah Kebomlati tahun pelajaran 2017/2018. Adapun nilai-nilai tersebut peneliti sajikan pada tabel di bawah ini.

\section{Tabel 1}

Jumlah Nilai Angket Penggunaan Game Online Android Siswa Kelas IV MI Islamiyah Kebomlati Kecamatan Plumpang Kabupaten Tuban

Tahun Pelajaran 2017/2018

\begin{tabular}{|c|c|}
\hline Nomor Subjek & Nilai \\
\hline 1 & 27 \\
\hline 2 & 26 \\
\hline 3 & 28 \\
\hline 4 & 25 \\
\hline 5 & 27 \\
\hline 6 & 28 \\
\hline 7 & 22 \\
\hline 8 & 26 \\
\hline 9 & 28 \\
\hline 10 & 26 \\
\hline 11 & 27 \\
\hline 12 & 22 \\
\hline
\end{tabular}




\begin{tabular}{|c|c|}
\hline 13 & 22 \\
\hline 14 & 19 \\
\hline 15 & 22 \\
\hline 16 & 24 \\
\hline 17 & 32 \\
\hline 18 & 28 \\
\hline
\end{tabular}

Berdasarkan hasil nilai angket di atas, peneliti akan menganalisis lebih lanjut data yang diperoleh. Sebagaimana yang telah peneliti kemukakan bahwa pertanyaan yang terdapat dalam angket setiap item mempunyai minimal nilai 1 dan maksimal nilai 4. Sedangkan item yang terdapat dalam angket adalah 10 item, maka setiap responden akan memperoleh nilai minimal 10 yaitu 1 x $10=10$ dan nilai maksimal 40 yaitu 4 × $10=40$. Dengan demikian nilai yang diperoleh responden adalah berkisar antara $10-40$.

Sehubungan dengan penjelasan data diatas, maka peneliti mengkatagorikan data tentang pengaruh game online android terhadap prestasi belajar siswa kelas IV MI Islamiyah Kebomlati kecamatan Plumpang kabupaten Tuban tahun pelajaran 2017/2018 dengan memberikan urutan kreteria. Dalam memberikan kriteria tersebut peneliti terlebih dahulu mengklasifikasikan hasil nilai yang diperoleh responden. Berikut kriterianya:

a. Nilai rata-rata antara 10 sampai 20 "kurang "

b. Nilai rata-rata antara 21 sampai 30 "cukup"

c. Nilai rata-rata antara 31 sampai 40 "sering"

Dari data nilai penggunaan game online android siswa kelas IV MI Islamiyah Kebomlati kecamatan Plumpang kabupaten Tuban tahun pelajaran 2017/2018 yang terdapat pada tabel di atas, diperoleh jumlah nilai 459 sehingga diperoleh rata-rata sebesar:

$$
\mathrm{M}=\frac{459}{18}=25,5
$$

Maka dapat diambil kesimpulan bahwa penggunaan game online android siswa kelas IV MI Islamiyah Kebomlati kecamatan Plumpang kabupaten Tuban tahun pelajaran 2017/2018 adalah cukup.

Dari hasil angket yang bernilai cukup dalam penggunaan game online android siswa kelas IV MI Islamiyah Kebomlati dikuatkan dengan hasil wawancara terhadap orang tua dan 
siswa bahwa siswa memainkan game online secara kadang-kadang biasanya dimainkan setelah pulang sekolah dan bagi siswa kelas IV MI Islamiyah Kebomlati kegiatan memainkan game online adalah suatu aktivitas yang tidak terlalu penting.

\section{Prestasi Belajar Siswa kelas IV MI Islamiyah Kebomlati kecamatan Plumpang kabupaten Tuban tahun pelajaran 2017/2018}

Data yang akan peneliti sajikan adalah data tentang prestasi belajar siswa kelas IV MI Islamiyah Kebomlati kecamatan Plumpang kabupaten Tuban tahun pelajaran 2017/2018. Data tersebut peneliti peroleh dari daftar nilai rata-rata penilaian tengah semester ganap dengan metode wawancara dengan wali kelas IV MI Islamiyah Kebomlati. Untuk lebih jelasnya dapat dilihat pada tabel berikut:

Tabel 2

\section{Daftar Prestasi Belajar siswa kelas IV MI Islamiyah Kebomlati kecamatan Plumpang kabupaten Tuban tahun pelajaran 2017/2018}

\begin{tabular}{|c|l|c|c|}
\hline NO & \multicolumn{1}{|c|}{ NAMA } & KELAS & $\begin{array}{c}\text { NILAI RATA RATA } \\
\text { RAPORT (PTS) }\end{array}$ \\
\hline 1 & Ni'matul Maulidia & IV & 68 \\
\hline 2 & Cinta Bella Febriana & IV & 72 \\
\hline 3 & Derick Ultan Jaya & IV & 74,9 \\
\hline 4 & Febby Adellia Ervanti & IV & 54,5 \\
\hline 5 & Ferdi Ardiansyah & IV & 60,9 \\
\hline 6 & Hanifatul Khofifah & IV & 80,8 \\
\hline 7 & Isna Aulia Bunga Nafisa & IV & 70,5 \\
\hline 8 & Lailidatin Nuha & IV & 77,25 \\
\hline 9 & Mischa Avrilya Firdausi & IV & 63,5 \\
\hline 10 & Moh. Muklis Hasanudin & IV & IV \\
\hline
\end{tabular}




\begin{tabular}{|c|c|c|c|}
\hline 11 & $\begin{array}{l}\text { Muhammad Fahri Al } \\
\text { Muhtaram }\end{array}$ & IV & 52,5 \\
\hline 12 & Muhammad Faisal Dwi Putra & IV & 60,9 \\
\hline 13 & $\begin{array}{l}\text { Muhammad Miftakhul } \\
\text { Rosyidi }\end{array}$ & IV & 60,7 \\
\hline 14 & Muhammad Musthofa & IV & 76,4 \\
\hline 15 & Niken Amelia & IV & 62,5 \\
\hline 16 & Saskia Raihan Rahmadani & IV & 64,4 \\
\hline 17 & Yuliani Rina Fajar Dini & IV & 82,5 \\
\hline 18 & Deswita Iz'zulfa Nurfajrina & IV & 76,5 \\
\hline \multicolumn{3}{|c|}{ JUMLAH } & 1220,7 \\
\hline
\end{tabular}

Berdasarkan tabel di atas, maka peneliti akan mengkategorikan data tentang prestasi belajar siswa kelas IV MI Islamiyah Kebomlati kecamatan Plumpang kabupaten Tuban tahun pelajaran 2017/2018. Dalam memberikan kriteria tersebut peneliti terlebih dahulu mengklasifikasikan hasil nilai yang diperoleh, yaitu dengan mencari rata-rata. Selanjutnya peneliti memberikan urutan kriteria tentang prestasi belajar siswa kelas IV MI Islamiyah Kebomlati tahun pelajaran 2017/2018 berdasarkan nilai rata-rata yang diperoleh, berikut kriterianya:
a. Nilai rata-rata 91 ke atas "sangat baik"
b. Nilai rata-rata 81 sampai 90 "baik"
c. Nilai rata-rata 75 sampai 80 "cukup"
d. Nilai rata-rata 74 ke bawah "kurang"

Dari data yang terdapat pada tabel prestasi belajar siswa kelas IV MI Islamiyah Kebomlati tahun pelajaran 2017/2018 di atas, diperoleh jumlah nilai 7953 sehingga diperoleh rata-rata sebesar:

$$
\mathrm{M}=\frac{1220,7}{18}=67,8
$$


Maka dapat diambil kesimpulan bahwa prestasi belajar siswa kelas IV MI Islamiyah Kebomlati kecamatan Plumpang kabupaten Tuban tahun pelajaran 2017/2018 adalah kurang.

\section{Pengaruh Game Online Android Terhadap Prestasi Belajar Siswa Kelas IV MI Islamiyah Kebomlati Kecamatan Plumpang Kabupaten Tuban Tahun Pelajaran $2017 / 2018$.}

Setelah menganalisa data dari kedua variabel maka dapat diketahui bahwa penggunaan game online android siswa kelas IV MI Islamiyah Kebomlati Kecamatan Plumpang Kabupaten Tuban Tahun Pelajaran 2017/2018 adalah cukup karena nilai rata-rata yang diperoleh adalah sebesar 25,5 dan berada pada interval 21-30 maka dinyatakan berpengaruh sedang. Sedangkan prestasi belajar siswa kelas IV MI Islamiyah Kebomlati Kecamatan Plumpang Kabupaten Tuban tahun pelajaran 2017/2018 adalah kurang karena nilai rata-rata yang diperoleh adalah sebesar 67,8 dan berada pada interval 74 ke bawah maka dinyatakan kurang. Kemudian untuk mengetahui ada tidaknya pengaruh game online terhadap prestasi belajar siswa kelas IV MI Islamiyah Kebomlati Kecamatan Plumpang Kabupaten Tuban tahun pelajaran 2017/2018 adalah menggunakan teknik statistik menghitung besarnya koefisien determinasi. Koefisien determinasi dan diuji dengan taraf signifikansi 5\%

\subsection{Pengujian Hipotesis}

Dalam pengujian hipotesis, peneliti akan menggunakan teknik statistik dengan mencari persamaan regresi sederhana, mencari koefisiens korelasi dan analisis tindak lanjut. Adapun peneliti merumuskan hipotesis penelitiannya menjadi dua bentuk hipotesis, yaitu :
a. Hipotesis Nihil (H0)
: Tidak ada pengaruh game online android terhadap prestasi belajar siswa kelas IV MI Islamiyah Kebomlati Kecamatan Plumpang Kabupaten Tuban tahun pelajaran 2017/2018.
b. Hipotesis Kerja (Ha) : Ada pengaruh game online android terhadap prestasi belajar siswa kelas IV MI Islamiyah Kebomlati Kecamatan Plumpang Kabupaten Tuban tahun pelajaran 2017/2018.

\section{Tabel 3}


Premiere Volume 1 No $1 \mid 2019$

Tabel Kerja Pengaruh Game Online Android Terhadap Prestasi Belajar Siswa Kelas IV MI Islamiyah Kebomlati Kecamatan Plumpang Kabupaten Tuban Tahun Pelajaran 2017/2018

\begin{tabular}{|c|c|c|c|c|c|}
\hline No. & $\mathbf{X}$ & $\mathbf{Y}$ & $\mathbf{X}^{2}$ & $\mathbf{Y}^{2}$ & $\mathbf{X Y}$ \\
\hline 1 & 27 & 68 & 729 & 4624 & 1836 \\
\hline 2 & 26 & 72 & 676 & 5184 & 1872 \\
\hline 3 & 28 & 62 & 784 & 3844 & 1736 \\
\hline 4 & 25 & 74,9 & 625 & 5610,01 & 1872,5 \\
\hline 5 & 27 & 54,5 & 729 & 2970,25 & 1471,5 \\
\hline 6 & 28 & 60,9 & 784 & 3708,81 & 1705,2 \\
\hline 7 & 22 & 80,8 & 484 & 6528,64 & 1777,6 \\
\hline 8 & 26 & 70,5 & 676 & 4970,25 & 1833 \\
\hline 9 & 28 & 77,25 & 784 & 5967,56 & 2163 \\
\hline 10 & 26 & 63,5 & 676 & 4032,25 & 1651 \\
\hline 11 & 27 & 52,5 & 729 & 2756,25 & 1417,5 \\
\hline 12 & 22 & 60,9 & 484 & 3708,81 & 1339,8 \\
\hline 13 & 22 & 60,7 & 484 & 3684,49 & 1335,4 \\
\hline 14 & 19 & 76,4 & 361 & 5836,96 & 1451,6 \\
\hline 15 & 22 & 62,5 & 484 & 3906,25 & 1375 \\
\hline 16 & 24 & 64,4 & 576 & 4147,36 & 1545,6 \\
\hline 17 & 32 & 82,5 & 1024 & 6806,25 & 2640 \\
\hline 18 & 28 & 76,5 & 784 & 5852,25 & 2142 \\
\hline$N=18$ & $\sum \mathbf{X}=\mathbf{4 5 9}$ & $\sum Y=1220,75$ & $\sum X^{2}=11873$ & $\sum Y^{2}=\mathbf{8 4 1 3 8 , 3 9}$ & $\sum X Y=31164,7$ \\
\hline
\end{tabular}


Keterangan:

$\mathrm{N} \quad$ : Jumlah subyek yang diteliti

$\sum \mathrm{X}$ : Jumlah skor distribusi $\mathrm{X}$

$\sum \mathrm{Y}$ : Jumlah Skor distribusi Y

$\sum X^{2}$ : Jumlah kuadrat skor distribusi $X$

$\sum \mathrm{Y}^{2}$ : Jumlah kuadrat skor distribusi $\mathrm{Y}$

XY : Jumlah perkalian skor X dengan Y

Dengan demikian perhitungan sebagai berikut,

$\mathrm{N}: 18$

$\sum \mathrm{X}: 459$

$\sum \mathrm{Y}: 1220,75$

$\sum \mathrm{X}^{2}: 11873$

$\sum \mathrm{Y}^{2}: 84138,39$

XY : 31164,7

a. Menentukan Koefisien Determinasi $\mathbf{R}^{2}$

$r=\frac{640,35}{8581,17} \quad r=0,0746$

$r=0,0746$ bernilai sangat rendah

artinya hubungan antara game online android terhadap prestasi belajar siswa kelas IV sangat lemah.

$R^{2}=0,0746^{2}=0,0055$

Artinya sekitar $0,5 \%$ variasi dari variabel penggunaan game online android dapat menjelaskan prestasi belajar siswa kelas IV (sangat rendah)

\section{b. Pengujian Koefisien Determinasi:}

1) Hipotesis Uji:

H0 $: \mathrm{b}=0$, (tidak ada pengaruh game online android terhadap prestasi belajar siswa kelas IV MI Islamiyah Kebomlati)

$\mathrm{Ha}: \mathrm{b} \neq 0$, (ada pengaruh game online android terhadap prestasi belajar siswa kelas IV MI Islamiyah Kebomlati).

2) Statistik uji. 


$$
t_{\text {hitung }}=\frac{r \sqrt{n-2}}{\sqrt{1-r^{2}}}=\frac{0,0746 \sqrt{18-2}}{\sqrt{1-0}, 0055}=\frac{0,298}{0,997}=0.298
$$

\section{3) Pada taraf signifikasi 5\% yaitu:}

$$
t_{t a b a l}=2.120
$$

\section{4) Keputusan}

Nilai t-hitung $=0,298<t-$ tabel $=2.120$ sehingga $\mathrm{H} 0$ diterima dan Ha ditolak.

\section{5) Kesimpulan}

Dengan tingkat signifikansi 5\% cukup menjelaskan bahwa tidak ada pengaruh game online android terhadap prestasi belajar siswa kelas IV MI Islamiyah Kebomlati Kecamatan Plumpang Kabupaten Tuban Tahun Pelajaran 2017/2018. Dari perhitungan ini berarti menunjukan terdapat korelasi negatif dan tidak signifikan antara pengaruh game online terhadap prestasi belajar siswa kelas IV MI Islamiyah Kebomlati Kecamatan Plumpang Kabupaten Tuban Tahun Pelajaran 2017/2018.

\section{E. Simpulan}

1. Penggunaan game online android siswa kelas IV MI Islamiyah Kebomlati Kecamatan Plumpang Kabupaten Tuban tahun pelajaran 2017/2018 adalah cukup atau berpengaruh sedang. Karena nilai rata-rata sebesar 25,5. Setelah dihitung rata-ratanya dapat diketahui bahwa rata-rata 25,5berada pada interval 21-30 maka dinyatakan cukup..

2. Adapun pengaruh game online android terhadap prestasi belajar siswa kelas IV MI Islamiyah Kebomlati Kecamatan Plumpang Kabupaten Tuban tahun pelajaran 2017/2018 berdasarkan hasil penelitian pada interpretasi menggunakan t-table nilai $r^{2}$ koefisien determinaasi, ternyata t-hitung $((0,298)$ lebih kecil dari t-tabel, pada taraf signifikasi $5 \%$ (2.120). Dengan demikian terdapat koefisien determinasi yang tidak signifikan antara game online android dan prestasi belajar siswa kelas IV MI Islamiyah Kebomlati Kecamatan Plumpang Kabupaten Tuban tahun pelajaran 2017/2018. Hal ini menunjukkan bahwa game online android tidak berpengaruh terhadap prestasi belajar siswa IV MI Islamiyah Kebomlati Kecamatan Plumpang Kabupaten Tuban tahun pelajaran 2017/2018.

3.

\section{REFERENSI}


Arikunto, Suharsimi. 1998. Pengertian Hipotesis. Jakarta: PT Reinka Cipta

Arikunto, Suharsimi. 2006. Prosedur Penelitian. Jakarta: PT Rineka Cipta

Arikunto, Suharsimi. 2010. Prosedur Pengumpulan Data. Jakarta: PT Rineka Cipta.

Arlina. 2016 Pengertian Pendidikan. Jakarta Erlangga.

Bloom, Benjamin S. 1956. Macam-macam Prestasi Belajar. Jakarta: Balai Pustaka

Depdikbud 1989. Kamus Besar Bahasa Indonesia. Jakarta: Balai Pustaka.

Dewey, Jhon. 1995. Education. Pengertian Pendidikan. Jakarta Erlangga.

Feances F. Merril. 1995 Pengertian Keluarga Jakarta Erlangga

Hadi, Sutrisno.2004. Statistik Pendidikan III. Yogyakarta: Fakultas Psikologi UGM

Hamalik. 1988 Pengertian Belajar Jakarta: Balai Pustaka

Hemiah, Iyanne. 2014. Dampak game Online Android, (Online), pada https://simpledukasi.blogspot.co. Diakses 30 Desember 2017.

Hilmuniati, Fina. 2011. Pedoman Penelitian Terdahulu, Dampak Game Online Android Dalam Pegamalan Ibadah Sholat. Jakarta: Universitas Indonesia

Lestari, Sri. 2012. Psikologi Keluarga: Penanaman Nilai dalam keluarga. Jakarta: Prenada Media Grup

Lumban, Theresia. 2012. Pedoman Penelitian Terdahulu. Jakarta: Fakultas Teknik Universitas Indonesia.

Mulya, Fajar. 2008 Pengertian Prestasi Belajar Yogyakarta: UGM

Nurgiantoro. Burhan, 1988 Indikator Belajar. Jakarta: Balai Pustaka

Prasetyo. 1996 Pengertian Rumusan Masalah

Rahim, Fitra. 2016. Pengertian Game Online, (Online), pada https://simpledukasi.blogspot.co.id. Diakses 30 Desember 2017. 
Rizal. 2014. Game vehicle Simulation, (Online), pada https://simpledukasi.blogspot.co. Diakses 24 Maret 2018.

Singarimbun, Masri. 1995. Rancangan Penelitia. Yogyakarta: Universitas Gajah Mada

Singarimbun. Masri,1995. Jenis Penelitian: Koefisien Determinasi. Jakarta: Balai Pustaka

Sudjana, Nana. 2009. Faktor-faktor Yang Mempengaruhi Prestasi Belajar. Jambi: Wakapolda

Sudjana, Nana. 2009. Hasil Proses Belajar Megajar. Jambi: Wakapolda

Thomas L Friedman. 2000. Pengertian Globalisasi Jakarta: Balai Pustaka

W.S. Winkel, 1996. Jenis-jenis Prestasi Belajar. Jakarta: Balai Pustaka

Widya. 2018. Jenis-jenis Game Online (Online), pada https://simpledukasi.blogspot.com. Diakses 23 maret 2018

Zainuddin.2008. Pengertian Terdahulu Jakarta: Universitas Indonesia 